\title{
PANCI STERILISASI UNTUK PENINGKATAN MUTU MINUMAN HERBA DI INDUSTRI RUMAH TANGGA KEL. BUMIAYU KOTA MALANG
}

\author{
Elik Murni Ningtias Ningsih ${ }^{1}$, Yuni Agung Nugroho ${ }^{2}$ \\ ${ }^{1,2}$ Program Studi Agroteknologi, Fakultas Pertanian, Universitas Widyagama \\ *Email Korespondensi: elikmurni@widyagama.ac.id
}

Submitted : 23 Juni 2021; Revision : 12 Juli 2021; Accepted : 2 Oktober 2021

\begin{abstract}
ABSTRAK
Industri Rumah Tangga (IRT) yang memproduksi minuman kesehatan herba di kelurahan Bumiayu Kota Malang yaitu IRT Widya Aktiva. Minuman herba untuk kesehatan yang diproduksi IRT Widya Aktiva diberi nama Jakuluh. Minuman kesehatan herba Jakuluh terbuat dari rimpang jahe, rimpang kunyit dan belimbing wuluh. Formulasi minuman kesehatan herba Jakuluh dibuat dengan proporsi tertentu yang menghasilkan minuman herba berguna untuk menjaga kesehatan. Mutu minuman herba dipengaruhi oleh proses produksinya. Proses sterilisasi pada produksi minuman herba yang dilakukan oleh IRT Widya Aktiva masih manual dengan pemanasan pada panci rebus biasa. Sterilisassi dengan panci biasa tidak terkontrol suhunya dan menghasilkan minuman herba dengan daya simpan relatif pendek. Minuman herba yang diproduksi oleh IRT Widya Aktiva bertahan selama 5 hari pada suhu kamar. Oleh karena itu diperlukan adanya alat yang memenuhi standar sterilisasi pada proses produksi minuman herba agar menghasilkan waktu simpan lebih lama pada suhu kamar. Metode yang dillakukan pada kegiatan meliputi penyuluhan, membuat desain dan merealisasikan pembuatan panci sterilisasi multi fungsi, demonstrasi dan pelatihan pemakaian panci sterilisasi multi fungsi serta pendampingan. Hasil pelaksanaan kegiatan penyuluhan mendapat respon yang baik yang dihadiri oleh anggota kelompok mitra industri rumah tangga Widya Aktiva. Panci sterilisasi yang didesign bersama mitra dapat memberikan efisiensi waktu (25\%) dan biaya (50\%) dibandingkan dengan sterilisasi menggunakan panci rebus biasa. Sterilisasi pada proses produksi minuman herba Jakuluh menggunakan panci sterilisasi multi fungsi menghasilkan minuman kesehatan herba dengan daya simpan selama 4 minggu. Peningkatan mutu minuman herba meningkatkan penjualan setiap minggu mencapai $200 \%$.
\end{abstract}

Kata kunci : Panci Sterilisasi, Mutu, Minuman, Herba, Industri Rumah Tangga

\begin{abstract}
The Home Industry (IRT) which produces herbal health drinks in the Bumiayu sub-district, Malang City, is IRT Widya Aktiva. The herbal drink for health produced by IRT Widya Aktiva is named jakuluh. Jakuluh herbal health drink is made from ginger rhizome, turmeric rhizome and starfruit. Jakuluh herbal health drink formulations are made with certain proportions that produce herbal drinks that are useful for maintaining health. The quality of herbal drinks is influenced by its production processes. The sterilization process in the production of herbal drinks carried out manually by IRT Widya Aktiva by heating in an ordinary boiled pot. Sterilization with an ordinary pot is not controlled by temperature and produces herbal drinks with a relatively short shelf life. The herbal drink produced by IRT Widya Aktiva lasts for 5 days at room temperature. Therefore, it is necessary to have a tool that meets sterilization standards in the production process of herbal drinks in order to produce a longer storage time at room temperature. The methods used in the activities include counseling, designing and realizing the manufacture of multi-function sterilization pot, demonstrations and training on the use of multi-function sterilization pot and mentoring. The results of the implementation of the extension activities received a good response which was attended by members of the home industry partner group. And participants understand the material that has been delivered. Widya Aktiva. Sterilization pots designed with partners can provide time (25\%) and cost (50\%) efficiency compared to sterilization using ordinary boiling pots. Sterilization in the Jakuluh herbal drink production process using a multi-function sterilization pot produces a
\end{abstract}


herbal health drink with 5 weeks of shelf life. Improvement on the quality of the herbal drinks increases sales every week by $200 \%$.

Keywords: Sterilization Pot, Quality, Beverage, Herbs, Home Industry

\section{PENDAHULUAN}

Kelurahan Bumiayu Kota Malang merupakan wilayah sentra industri rumah tangga. Sebagian masyarakat kelurahan Bumiayu sebagai produsen minuman herba untuk kesehatan. Industri Rumah Tangga (IRT) yang memproduksi minuman kesehatan herba yaitu IRT Widya Aktiva. Produksi minuman kesehatan herba tersebut sebagai bagian dari sumber mata pencaharian. Minuman kesehatan herba berasal dari rempah-rempah menghasilkan antioksidan yang berguna untuk menjaga kesehatan (Septiana, et al., 2017).

Minuman herba untuk kesehatan yang diproduksi IRT Widya Aktiva diberi nama Jakuluh. Minuman herba Jakuluh berdasarkan fungsinya sebagai minuman fungsional. Jakuluh sebagai minuman fungsional mempunyai dua fungsi utama yaitu sebagai sumber asupan gizi serta rasa yang enak dan tekstur yang baik sebagai pemuas sensori (Septiana, et al., 2017). Formulasi atau bahan campuran pada minuman herba menjadi bagian terpenting dari minuman fungsional agar minuman herba yang dihasikan mempunyai cita rasa yang disukai masyarakat dan mempunyai fungsi menjaga kesehatan.

Minuman herba berupa sirup Jakuluh adalah sirup hasil produksi IRT Widya Atktiva terbuat dari bahan jahe, kunyit dan belimbing wuluh (Jakuluh) yang mengandung antioksidan, vitamin $\mathrm{C}$ dan fosfor yang tinggi sehingga bermanfaat untuk menjaga kesehatan tubuh, mengurangi gejala batuk dan mengobati penyakit diabetes (Sulistiani, Tamrin dan Baco, 2019).

Jumlah produksi minuman kesehatan herba IRT Widya Aktiva dipengaruhi oleh kondisi musim. Saat musim kemarau atau panas memproduksi minuman kesehatan herba 2 kali dalam satu minggu sedangkan pada musim hujan memproduksi 3 kali dalam seminggu. Pemasaran produk selama ini tidak menjadi kendala yang berarti karena langsung dipasarkan IRT "Kelompok Widya Aktiva" minuman kesehatan herba yang dipasarkan dengan menitipkan pada toko-toko kelontong dan dijual di rumah produksi. Penjualan minuman herba Jakuluh yang diproduksi IRT Widya Aktiva sebanyak 100 botol per bulan.

Mutu minuman herba dipengaruhi oleh bahan, formula dan proses produksinya. Bahan minuman herba berasal dari rempah tanaman toga jahe, kunyit dan blimbing wuluh yang dipilih dengan kualitas rimpang dan buah segar. Khasiat rempah-rempah jahe mengandung antioksidan (Sulistiani, et al., 2019). Kunyit sebagai antirematik dan blimbing wuluh sebagai sumber vitamin $\mathrm{C}$, Zat yang ada pada rimpang jahe berupa asam-asam organik berupa malat, oksalat, asam laurat, palmitat, oleat, linoleat dan stearate sebagai antioksidan (Yulianto dan Widyaningsih, 2013).

Mutu minumnan herba Jakuluh dipengaruhin oleh kebersihan pada saat proses produksi. Menjaga kebersihan pada proses produksi minuman herba dilakukan dengan sterilisasi pada botol untuk kemasan. Proses sterilisasi pada produksi minuman herba yang dilakukan oleh IRT Widya Aktiva dengan pemanasan pada panci biasa dengan diameter 25 $\mathrm{cm}$. Botol-botol yang akan dipakai untuk mengemas hasil olahan minuman herba Jakuluh disterilisasi dengan memanaskan botol-botol ke dalam air mendidih selama 30 menit. Hasil minuman herba yang dikemas dengan sterilisasi sederhana memberikan daya tahan terhadap munuman selama 5 hari pada suhu kamar. Sterilisasi dengan merebus botol pada panci biasa tidak dapat menjaga kestabilan suhu selama sterilisasi. Disebutkan oleh Herastuti et al. (2000) sterilisasi merupakan proses membunuh bakteri pada suhu tinggi $\left(121{ }^{\circ} \mathrm{C}\right)$. Sehingga perlu dilakukan perbaikan pada proses sterilisasi yang mampu meningkatkan mutu minuman herba yang tahan penyimpanan pada suhu kamar dengan waktu lebih panjang. 


\section{PERMASALAHAN}

Berdasarkan hasil identifikasi dan analisis situasi didapatkan permasalahan yang dihadapi oleh mitra yaitu pada sterilsasi botol untuk kemasan pada proses produksi minuman herba Jakuluh. Proses sterilisasi menggunakan sterilisasi manual dengan panci biasa. Pelaksanaan sterilisasi botol kemasan masih meggunakan panci biasa diameter 25 $\mathrm{cm}$ dengan cara merebus botol. Hasil sterilisasi dengan panci masak biasa menghasilkan botol kemasan tidak tersterilisasi secara optimal sesuai standar sterilisasi. Produksi minuman herba Jakuluh dengan sterilisasi menggunakan panci masak biasa menghasilkan produk minuman herba Jakuluh dalam kemasan botol kaca tahan selama 5 hari di suhu ruang. Jangka waktu simpan yang relatif pendek pada suhu ruang/kamar akan mendatangkan kerugian, jika dalam waktu 5 hari tidak laku terjual maka minuman kesehatan herba sudah tidak dapat dijual. Upaya peningkatan mutu minuman herba Jakuluh pada proses produksi memerlukan alat sterilisasi berupa panci sterilisasi multi fungsi yang terkontrol suhu dan tekanannya.

\section{METODE}

Metode yang dipakai pada kegiatan meliputi:

1. Penyuluhan, kegiatan penyuluhan dilakukan pada awal kegiatan dilaksanakan untuk menyampaikan materi terkait dengan sterilisasi pada produksi minuman herba. Kegiatan penyuluhan dilaksanakan pada minggu pertama kegiatan. Evaluasi keberhasilan kegiatan penyuluhan dilakukan mengukur capaian jumlah peserta yang hadir dan pemahaman terhadap materi yang telah dilakukan dengan isian pertanyaan pada quisioner.

2. Membuat desain panci strelisasi multi fungsi model "Autoklaf" yang dilengkapi dengan penunjuk suhu dan tekanan. Kegiatan desain panci sterlisasi multi fungsi dilaksanakan pada minggu ke 2 dsn 3 dengan melibatkan mitra.

3. Membuat panci strelisasi multi fungsi. Kegiatan pembuatan panci sterlisasi dilaksanakan pada minggu $4-6$ dengan melibatkan mitra pembuat alat pengolahan makanan.

4. Demonstrasi dan pelatihan, yaitu kegiatan melakukan demonstrasi dan melatih pemakaian alat yang sudah dibuat kepada mitra untuk mengecek kemampuan alat dan melatih ketrampilan mitra. Evaluasi capaian pada kegiatan pelatihan dengan menilai ketrampilan secara teknis melakukan sterilisasi dan dampak dari pelatihan.

5. Pendampingan, kegiatan pendampingan dilaksanakan selama 1 bulan dan mengevaluasi dampak hasil pelatihan yang telah dilakukan.

\section{HASIL DAN PEMBAHASAN}

Pelaksanaan kegiatan dimulai dengan penyuluhan pada mitra IRT Widya Aktiva. Kegiatan penyuluhan yang dilaksanakan dengan materi sterilisasi pada pengolahan minuman herba dan manfaat minuman herba. Kegiatan penyuluhan meliputi materi mengenai proses sterilisasi produksi minuman kesehatan herba. Materi tersebut disampaikan untuk menambah wawasan dan pemahaman mitra kelompok IRT Widya Aktiva untuk menunjang pelaksanaan pengelolaan produksi minuman herba Jakuluh yang dihasilkan menjadi lebih baik. Kegiatan penyuluhan diikuti oleh peserta mitra kelompok IRT Widya Aktiva sebanyak 8 orang anggota IRT Widya Aktiva. Para peserta berperan aktif pada saat diskusi dengan meyampaikan kondisi riil yang ada dan saling memberikan masukan. Evaluasi pelaksanaan kegiatan penyuluhan dengan memberikan beberapa pertanyaan melalui quisioner sesuai dengan materi yang telah disampaikan. Hasil kegiatan menunjukkan bahwa semua peserta (100\%) telah memahami materi yang telah diberikan. Pelaksanaan kegiatan penyuluhan disajikan pada Gambar 1. 

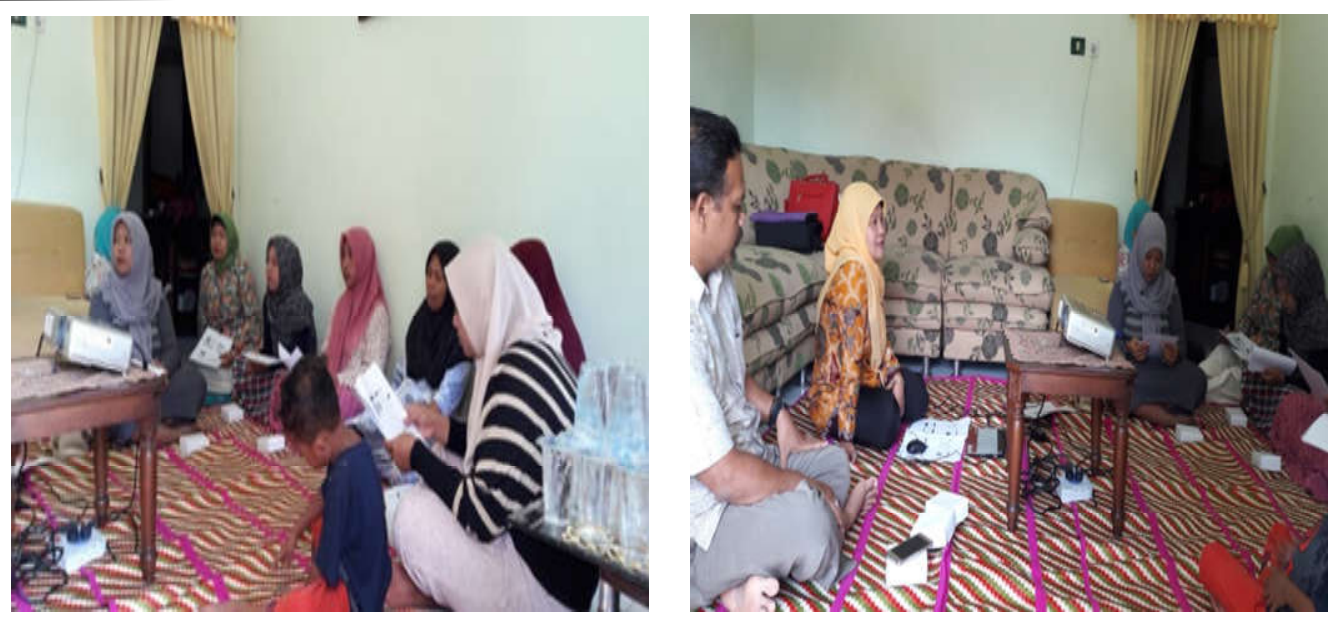

Gambar 1. Pelaksanaan Penyuluhan Pada Mitra Industri Rumah Tangga Widya Aktiva.

Minuman kesehatan herba yang diproduksi oleh IRT Widya Aktiva berupa Jakuluh. Minuman herba Jakuluh dibuat dari bahan jahe, kunyit dan belimbing wuluh dengan takaran tertentu (jahe: kunyit : belimbing wuluh dengan perbandingan $1: 1: 1 / 4$ ). Semua bahan yang segar dibersihkan dan dihaluskan selanjutnya direbus sampai mendidih. Rasa minuman herba Jakuluh beraroma sedap dan rasa yang segar. Pembuatan minuman herba sebagai makanan fungsional memerlukan formula tertentu untuk menghasilkan cita rasa disukai konsumen (Septiana, Samsi, Mustaufik. 2017). Rasa dominan pedas pada jahe disebabkan senyawa keton, zingeron yang memeberi rasa hangat (Supriani, 2019).

Peningkatan kualitas sterilisasi pada proses produksi minuman herba dilaksanakan dengan pembuatan design panci sterilisasi multi fungsi yang selanjutnya direalisasikan pembuatannya. Mendesign panci sterilisasi multi fungsi dilakukan dengan mitra IRT Widya Aktiva. Panci sterilisasi multi fungsi terdiri dari rangkaian panci ada penunjuk suhu dengan dilengkapi pemanas kompor elpiji. Panci sterilisasi multi fungsi dilengkapi pengukur tekanan dan suhu atau steam boiler/manometer, sehingga pada proses sterilisasi suhu dan tekanan uap terkontrol sesuai dengan syarat sterlisasi yang memenuhi standar sterilisasi.

Setelah design panci sterlisasi multi fungsi disepakati dilanjutkan dengan pembuatan panci sterilisasi multi fungsi. Pembuatan panci sterilisasi multi fungsi melibatkan mitra tenaga kerja pembuat alat pengolahan makanan. Bahan panci sterilisasi multi fungsi menggunakan bahan stainless stell, sedangkan rangka penopang panci sterilisasi menggunakan besi sesuai design. Hasil pembuatan panci sterilisasi multi fungsi disajikan pada Gambar 2 dan Gambar 3.

Kegiatan demonstrasi dan melatih pemakaian panci sterilisasi multi fungsi dilakukan pada mitra IRT Widya Aktiva. Panci sterilisasi digunakan untuk mensterilkan botol kaca dan minuman herba dalam kemasan botol kaca. Panci sterilisasi multi fungsi dapat mengefisienkan proses produksi dari segi tenaga dan waktu serta pensterilan sesuai standar sterilisasi. Kegiatan demonstrasi dan pelatihan pemakaian panci sterilisasi multi fungsi disajikan pada Gambar 4. Proses sterilisasi dilakukan pada botol kosong dan botol yang telah terisi minuman herba. Proses sterilisasi dilakukan pada suhu $121^{\circ} \mathrm{C}$ selama 15 menit. Dijelaskan oleh Herastuti et al. (2000), bahwa untuk sterilisasi produk kemasan botol kaca dilakukan pada suhu $121^{\circ} \mathrm{C}$ selama 15 menit guna membunuh mikroba.

Pemakaian panci sterilisasi multi funsi memberikan beberapa keuntungan. Keuntungan sterilisasi memakai panci sterilisasi multi fungsi jumlah botol pada setiap sterilisasi lebih banyak dan minuman herba yang dihasilkan dapat tahan lebih lama pada suhu ruang yaitu selama 4 minggu. Waktu sterilisasi menggunakan pansi sterilisasi lebih efisien yaitu selama 15 menit. Biaya untuk mensterilisasi memakai panci sterilisasi multi 
fungsi lebih sedikit. Keuntungan pemakaian panci sterilisasi multi fungsi disajikan pada Tabel 1.

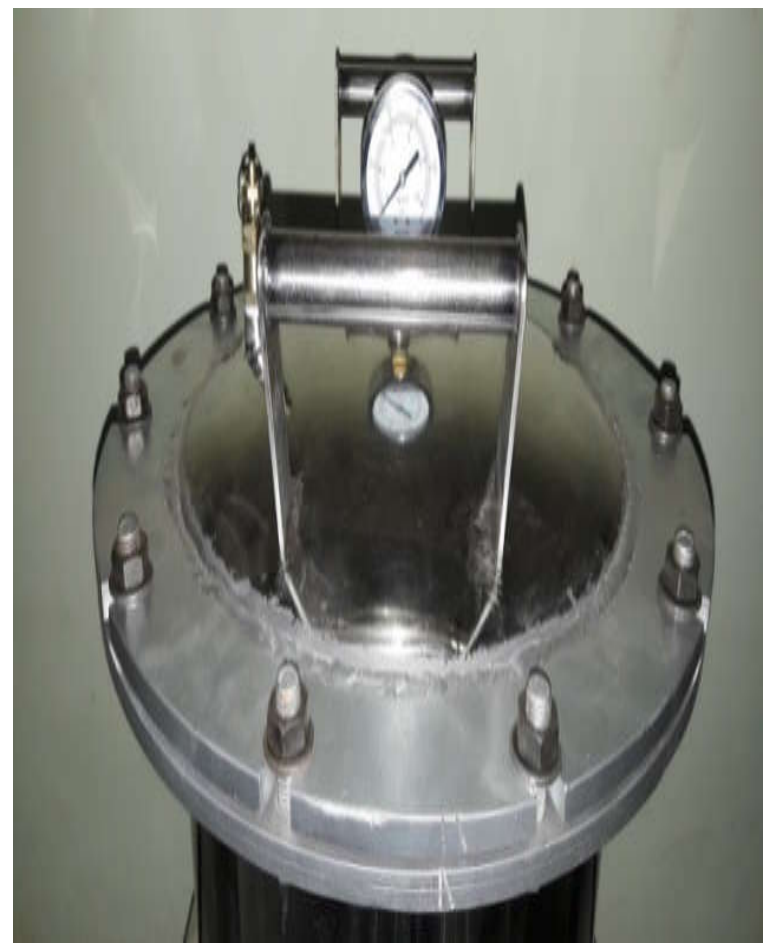

Gambar 2. Bagian Atas Panci Sterilisasi Multi Fungsi

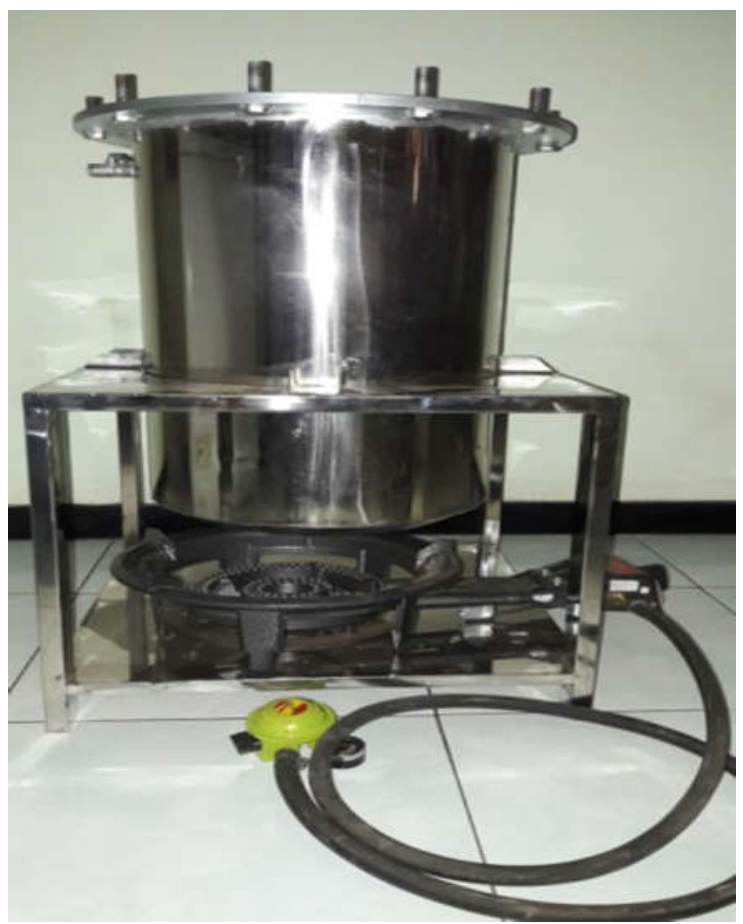

Gambar 3. Rangkaian Gambar Panci Sterilisasi Dan Kompor 
Tabel 1. Efisiensi Sterilisasi Dengan Panci Biasa Dan Panci Sterilisasi Multi Fungsi

\begin{tabular}{|c|l|l|l|}
\hline No & \multicolumn{1}{|c|}{ Keterangan } & \multicolumn{1}{|c|}{$\begin{array}{c}\text { Panci biasa diameter } \\
\mathbf{3 0} \mathbf{~ c m}\end{array}$} & $\begin{array}{c}\text { Panci Sterilisasi } \\
\text { (Autoklaf) Multi Fungsi }\end{array}$ \\
\hline 1 & Kapasitas botol $600 \mathrm{ml}$ & 8 botol & 20 botol \\
\hline 2 & Penampungan botol & $\begin{array}{l}\text { Botol yang masuk ke } \\
\text { dalam panci 3/4 bagian }\end{array}$ & $\begin{array}{l}\text { Botol dapat masuk } \\
\text { keseluruhan }\end{array}$ \\
\hline 3 & $\begin{array}{l}\text { Temperatur dan } \\
\text { tekanan dalam panci }\end{array}$ & Tidak terukur & $\begin{array}{l}\text { Terukur dan dapat } \\
\text { dikontrol }\end{array}$ \\
\hline 4 & Standar sterilisasi & $\begin{array}{l}\text { Tidak memenuhi } \\
\text { standar sterilisasi }\end{array}$ & $\begin{array}{l}\text { Memenuhi standar } \\
\text { sterilisasi }\end{array}$ \\
\hline 5 & Waktu sterilisasi & 30 menit & 15 menit \\
\hline 6 & Biaya elpiji & Rp. $8000,-$ & Rp. 4000 \\
\hline 7 & $\begin{array}{l}\text { Daya simpan di suhu } \\
\text { ruang }\end{array}$ & 5 hari & 4 minggu \\
\hline
\end{tabular}

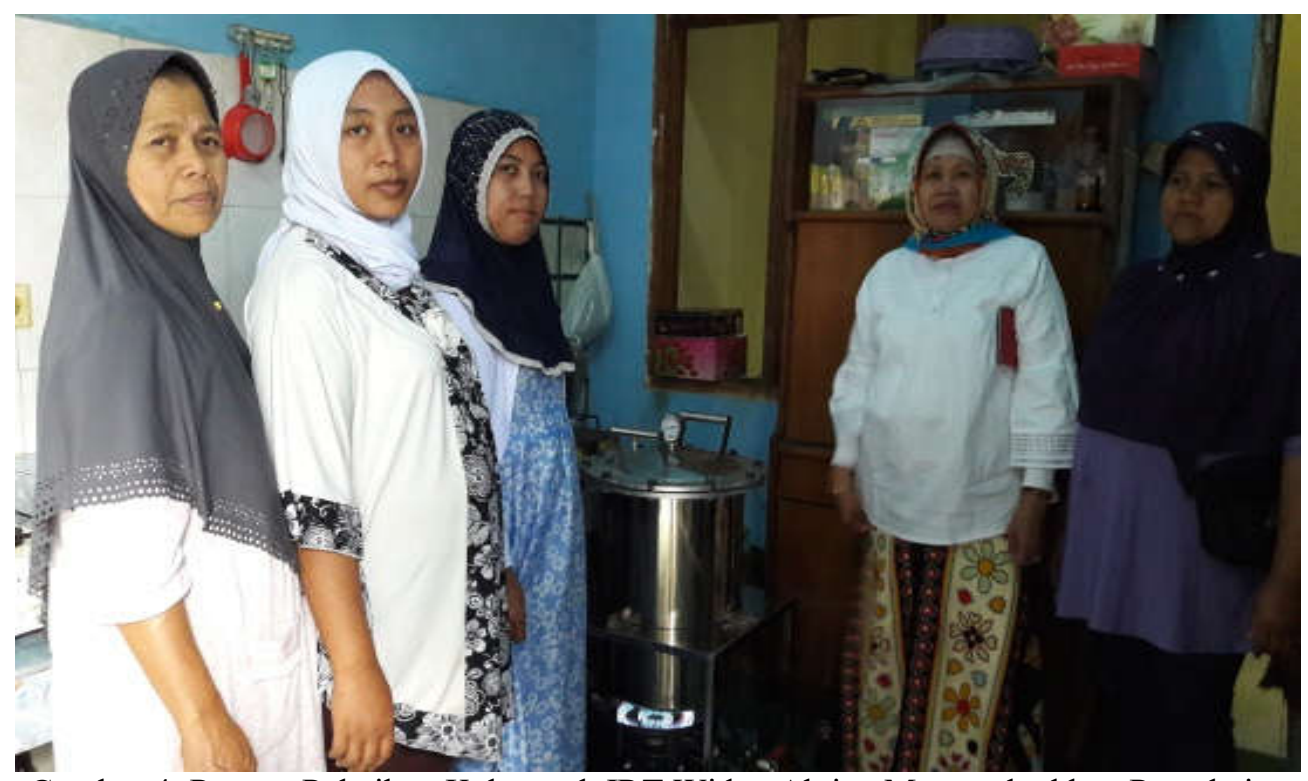

Gambar 4. Peserta Pelatihan Kelompok IRT Widya Aktiva Mempraktekkan Pemakaian Panci Sterilisasi Multi Fungsi

Pendampingan proses produksi dilakukan pada pemakaian alat panci sterilisasi yang telah dibuat dan proses produksi minuman herba Jakuluh. Pelatihan dan Pendampingan untuk melatih kemampuan mitra dalam penggunaan panci sterilisasi multifungsi dilakukan secara periodik setiap minggu dan mengevaluasi hasil penjualannya.

\section{DAMPAK DAN MANFAAT}

Kegiatan yang telah dilaksanakan memberikan beberapakan dampak dan manfaat pada mitra IRT Widya Aktiva. Kegiatan penyuluhan dan pelatihan berdampak pada peningkatan pengetahuan dan ketrampilan mengenai sterilisasi pada proses produksi minuman herba. Manfaat secara langsung pada Kelompok IRT Widya Aktiva dapat memproduksi minuman kesehatan herba Jakuluh dengan mutu kebersihan sesuai dengan 
standar sterilisasi pada proses produksi minuman herba dan menghasilkan minuman herba Jakuluh dengan daya simpan pada suhu kamar yang panjang (4 minggu).

Pemakaian panci sterilisasi multi fungsi pada proses produksi dan peningkatkan daya tahan minuman herba memberi dampak pada peningkatan jumlah penjualan minuman herba Jakuluh. Penjualan minuman herba Jakuluh yang sebelumnya hanya 20 botol/minggu, setelah daya tahan untuk disimpan di suhu ruang bertambah panjang, penjualan minuman herba Jakuluh mengalami peningkatan yaitu rata-rata penjualan selama 1 minggu sebesar $60-80$ botol. Peningkatan pendapatan dari penjualan minuman herba Jakuluh dari Rp. 400.000,- meningkat menjadi Rp. 1.200.000,- sampai Rp. 1.600.000,-. Peningkatan jumlah penjualan secara ekonomi mempengaruhi peningkatan pendapatan pada produsen IRT Widya Aktiva.

\section{KESIMPULAN}

Pelaksanaan kegiatan penyuluhan mendapat respon yang baik yang dihadiri oleh anggota kelompok mitra industri rumah tangga Widya Aktiva dan meningkatkan pengetahuan produksi minuman herba. Alat penunjang proses produksi yang telah didesign bersama mitra dapat memberikan efisiensi waktu (25\%) dan biaya (50\%). Proses sterilisasi dengan panci sterilisasi multi fungsi pada proses produksi menghasilkan minuman kesehatan herba Jakuluh dengan daya simpan pada suhu kamar selama 4 minggu. Peningkatan mutu minuman herba Jakuluh meningkatkan penjualan setiap minggu mencapai $200 \%$.

\section{UCAPAN TERIMA KASIH}

Ucapan terimakasih disampaikan kepada mitra industri IRT Widya Aktiva yang telah berperan aktif pada pelaksanaan kegiatan tersebut.

\section{REFERENSI}

Herastuti, S., Wiworo, H., Hidayati, S., Maria, and Bakri, H. (2020) 'Panci Tekan Sebagai Alat Sterilisasi’, http://eprints.poltekkesjogja.ac.id > pancitekan (diakses 19 Oktober 2020).

http://oikprinces.blogspot.co.id/p/dttsterilisasi.html. Desinfaksi Tingkat Tnggi dan sterilisasi. Diakses 26 Maret 2016.

Septiana, A. T., Samsi, M. and Mustaufik, M. (2017) 'Pengaruh Penambahan Rempah dan Bentuk Minuman terhadap Aktivitas Antioksidan Berbagai Minuman Tradisional Indonesia', AGRITECH, 37(1), pp. 7-14.

Sulistiani, P. N., Tamrin, A. R. and Baco1 (2019) 'Kajian Pembuatan Minuman Fungsional Dari Daun Sirsak (Annona Muricata Linn.) Dengan Penambahan Bubuk Jahe (Zingiber Officinale)', J. Sains dan Teknologi Pangan, 4(2) pp. $2085-2095$.

Supriani, A. (2019) 'Peranan Minuman Dari Ekstrak Jahecang Untuk Meningkatkan Kesehatan Masyarakat', Jurnal Sain Health, 3(1), pp. 30-39.

Yulianto, R. R., and Widyaningsih, T. D., (2013) 'Formulasi Produk Minuman Herbal Berbasis Cincau Hitam (Mesona Palustris), Jahe (Zingiber Officinale), dan Kayu Manis (Cinnamomum Burmanni)', Jurnal Pangan dan Agroindustri, 1(1), pp. 6577. 